\title{
Effect of intercropping sunflower with legumes on some sunflower morphological traits
}

\author{
Brankica Babec ${ }^{1 *}$. Srđan Šeremešić ${ }^{2}$ Nada Hladni' $\cdot$ Sreten Terzić ${ }^{1} \cdot$ Bojan Vojnov ${ }^{2}$. \\ Nemanja Ćuk ${ }^{1}$. Sonja Grozdenac' \\ ${ }^{1}$ Institute of Field and Vegetable Crops, Novi Sad, Serbia \\ ${ }^{2}$ University of Novi Sad, Faculty of Agriculture, Novi Sad, Serbia
}

\begin{abstract}
Summary: Given that climate change is a burning issue, agriculture must turn to more sustainable and environmentally friendly systems, counting intercropping. Within a two-year study of intercropping sunflower with legumes, the influence of this system on sunflower plant height and head diameter was investigated. The aim of research was to evaluate the effects of sunflower-legume intercropping on these traits, considering the possibility of competition between crops. The field trial was set up in April 2017 and 2018 at Institute of Field and Vegetable Crops, Novi Sad, Republic of Serbia experimental field in moderate-continental climate. Year 2017 was extremely arid with the sum of precipitation different compared to 2018. Plant height and head diameter of hybrids Rimi PR, Dukat and NS Gricko, intercropped with common vetch, red clover and alfalfa were compared with control, i.e. same sunflower hybrids grown as a sole crop. It was observed that intense growth of common vetch suppressed the growth of sunflower, and led to a decrease in measured traits in all three hybrids. Results indicated that the following combinations of sunflower and legumes are most desirable: NS Gricko/RC, Dukat/ALF, Dukat/RC and Rimi PR/ $\mathrm{RC}$ depending on the agro-ecological conditions. Given that the experiment was performed in years that varied significantly in agro-ecological conditions, the results indicated that red clover and alfalfa can mitigate the negative effects caused by lack of precipitation and high temperatures. In order to better understand all aspects of sunflowerlegume intercropping, further research, which should include other morphological, qualitative and quantitative indicators, is needed.

Key words: sunflower, legumes, intercropping, plant height, head diameter
\end{abstract}

\section{Introduction}

Sunflower (Helianthus annuns L.) is one of the five major oil crops in the world along with soybeans and rapeseed (Šimić et al., 2008; Seiler et al., 2017). In recent years, the areas under this crop in the Republic of Serbia (RS) have ranged between 200 and 250 thousand hectares (Čurović, 2018). In addition to the oil type, which is mostly sown, confectionary sunflower type is also grown. Although production of this type is less than five percent, the demand for confectionary sunflower is growing due to its nutritional value and increasing use in human nutrition (Hladni \& Miladinović, 2019). Sunflower seed yield depends on various morphological traits, and head diameter,

Corresponding author:

brankica.babec@ififvcns.ns.ac.rs

Cite this article:

Babec B., Šeremešić S., Hladni N., Terzić S., Voinov B., Ćuk N., Gvozdenac S. (2020). Effect of intercropping sunflower with legumes on some sunflower morphological traits. Ratar. Povrt., 57 (2), 61-67. together with the plant height, is important with direct effect on seed yield per plant (Hladni et al., 2014). Traits as number of flowers, and consequently the number of seeds per head, depend on the head diameter (Mrda, 2015). To achieve high seed yield per unit area, the competitive ability of the genotype to provide an average of over 1500 seeds per sunflower head, in a dense plant stand, is important (Hladni, 2007). In order to obtain this number of seeds, head diameter is essential. The smallest head diameter is found in early hybrids and the largest in late hybrids (Miklič et al., 2011). Plant height through the size of the leaf area and the length of the petiole indirectly affects seed yield (Kaya, 2016). The most intense growth of the stem takes place in the stages from bud phase to flowering, and during this period the daily growth is from 7 to 12 $\mathrm{cm}$, ending with flowering. Very tall plants are susceptible to lodging in heavy rainfall and stormy winds especially during and after the grain filling phase, which can significantly reduce seed yield. The optimum height of sunflower plants in production is between 160 and $180 \mathrm{~cm}$, although there are half-bushy genotypes whose height is $120-160 \mathrm{~cm}$ and dwarf with height from 100 to 
$120 \mathrm{~cm}$. Also, there are genotypes over two meters in height (Kaya et al., 2011). This trait is susceptible to changes caused by agroecological conditions, and therefore the optimal height cannot be generalized as it depends on the growing region. Intensive sunflower production is followed by intensive cultivation practices. This crop requires 40-50 kg N, 15-20 kg $\mathrm{P}_{2} \mathrm{O}_{5}$ and 80$100 \mathrm{~kg} \mathrm{~K} \mathrm{~K}_{2} \mathrm{O}$ for $1 \mathrm{t} / \mathrm{ha}$ of seeds and a suitable vegetative mass. It is known that by ploughing sunflower harvest residues, sunflower returns $40-50 \% \mathrm{~N}, 30-40 \% \mathrm{P}_{2} \mathrm{O}_{5}$ and $80-90 \%$ of $\mathrm{K}_{2} \mathrm{O}$ (Crnobarac et al., 2005), indicating a significant potential of plant residues when it comes to preserving soil fertility.

Agriculture is an economy sector that is particularly vulnerable to climate change, since its production takes place mostly on fields. The increased frequency of extreme weather conditions in RS, but also in the world, will contribute to increasing restrictions in the conventional production of sunflower, which is based on the intensification of cultivation through increased inputs to improve yield. However, intensive cultivation practices cannot compensate for adverse weather conditions, leading to a number of side effects such as land degradation through increased use of chemicals, reduction of biodiversity, etc. Under the current and projected climate changes more attention must be given to this problem, and intercropping, as a sustainable type of agricultural production, may be a possible way towards a solution.

Notwithstanding extensive research in the field of sunflower cultivation practices, which has been conducted under semiarid conditions of RS, no significant studies of sunflower intercropping have been conducted so far. Intercropping, the system of cultivation of multiple plant species in one field, represents the practical application of ecological principles based on biodiversity, and interactions between plants and natural regulatory mechanisms. The literature indicates significant benefits of intercropping in terms of increased yield per unit area, better use of available resources, significantly reduced use of pesticides, etc. (Bokan et al., 2016; Martin-Guay et al., 2018; Šeremešić et al., 2018). Legumes can have a beneficial effect on yield, and other plant characteristics while reducing the cost of nitrogen and pesticide application, and therefore positive effect on profits (Ugrenović et al., 2014). Legumes can reduce restrictions on nitrogen of another species that are intercropped with, which can result in an improvement in overall productivity (de la Fuente et al., 2014). HaugaardNielsen et al. (2001) indicated that percentage of nitrogen uptake by legumes was much higher when intercropping these plants with non-legume ones, in comparison to growing in monoculture.

As already mentioned, in RS agro-ecological conditions, substantial agricultural problems have been created in recent years by the uneven distribution of rainfall during the growing season, and the increased frequency of extreme weather events in recent years requires strategic management of agro-ecosystems. Lalić et al. (2011) indicated that the lack of precipitation in both winter and summer is one of the main limiting factors for agricultural production, and a similar trend is predicted in the future. Quite a few species from the leguminous family act as live mulch and thus reduce the loss of water by surface runoff (Singh et al., 2015). Intercropping contributes to a better use of the available amounts of water due to the usually different depth to which the root system of the plants penetrates (Ren et al., 2014; Martin-Guay et al., 2018). In addition, Martin-Guay et al. (2018) stated that usually two crops respond differently to water shortages, i.e. one is always less sensitive. In this way, polyculture increases the safety of production relative to monoculture.

Growing more plant species per unit area can lead to increased competition for basic plant growth and development factors. Increased competition (interspecific and intraspecific) usually leads to a decrease in yield of one or even both crops, however legumes can often have a positive competitive relationship with the other plant species with which they are intercropped, all with the aim of increasing productivity per unit area, or overall yield of intercrops.

Taking all the foregoing into account, the aim of the study was to determine the influence of intercropping sunflower with legumes on selected morphological trait of sunflower related to the yield, and to examine the possibility of sunflower production in intercropping system for all its benefits. The morphological traits examined in the study are the plant height and the head diameter. The objective derives from the fact that intercropping is a type of production in which competition among the species is usually present, but it has numerous advantages over the conventional production described above. Furthermore, after harvesting the sunflower, red clover and alfalfa can remain as already established crops for next year's animal feed production, and during the sunflower production legumes can reduce the needs for nitrogen and preserve the soil.

\section{Material and Methods}

The experiment was conducted in 2017 and 2018 at the experimental field of the Institute of Field and Vegetable Crops, Novi Sad, Serbia at Rimski Šančevi (4520'32.2"N 1951'42.8"E), and plant height and head diameter of three different sunflower hybrids were measured - two oil types (Rimi PR and Dukat) and one confectionary type (NS Gricko). Given that alfalfa, red clover, field pea and vetch are the most important and the most widely distributed forage legumes in RS, these hybrids were intercropped with common vetch (Vicia sativa L., Novi Beograd variety), red clover (Trifolium pratense L., Una variety) and alfalfa (Medicago sativa L., Banat VS variety), and compared to the same hybrids grown as a sole crop in control treatment (C).

The cultivation practices implemented are the same as in the production conditions of RS. The experiment 
was set up in four repetitions, and the size of the basic plot was $9 \times 3.5 \mathrm{~m}$, with $1.5 \mathrm{~m}$ spacing between treatments, i.e. legume, and repetitions. Sorghum was the preceding crop. Sunflower sowing was carried out at the optimum time. Common vetch $(\mathrm{CV})$, red clover (RC), and alfalfa (ALF) were sown two days after sowing sunflower. Keeping in mind the possible competence and its negative impact on sunflower, the sowing date of all plant species is uniform. Sunflower was sown with Wintersteiger PSP Single Disk seeder in six rows, with a row spacing of $70 \mathrm{~cm}$ and a $25 \mathrm{~cm}$ spacing of plants in row. Legumes were sown with Amazone 08-30 Super seed drill (seeder). The sowing rate of red clover and alfalfa was $18 \mathrm{~kg} \mathrm{ha}^{-1}$ and the common vetch $120 \mathrm{~kg} \mathrm{ha}^{-1}$, the same as in for biomass production. The sample size for the measurement was 10 plants per repetition. Plant height and head diameter of the sunflower were measured in full flowering, i.e. BBCH 65 phase (Lancashire et al., 1991), in field conditions.

The main climatic factors (temperature and precipitation) for the period from April to October 2017 and 2018, taken from the Meteorological
Yearbook of the Republic Hydro-Meteorological Institute, are showed at Walter climate diagram (Figure 1). In 2017, $82.9 \mathrm{~mm}$ of precipitation fell in May, and $12.0 \mathrm{~mm}$ and $17.4 \mathrm{~mm}$ respectively in July and August, with extremely high temperatures in these two months. The average daily temperature during the growing season was $19^{\circ} \mathrm{C}$. In 2018, May had about $20 \mathrm{~mm}$ less precipitation than in 2017, but June was extremely humid with $163.2 \mathrm{~mm}$ of precipitation, which is about $100 \mathrm{~mm}$ more than in 2017 . July precipitation was also above the 50-years average $(81.2 \mathrm{~mm})$. In 2018 average daily temperature during the growing season was $19.8^{\circ}$ C. The beginning of growing period in April that year was extremely warm with an average daily temperature of $17.2^{\circ} \mathrm{C}$. The average daily temperatures in both years were above the 50-years average.

Data were analysed using two-way analysis of variance (two-way ANOVA) to differentiate sunflower characteristics in relation to the hybrid, treatment i.e. legumes, and their interaction. Duncan test was used to determine differences in mean values, i.e. to compare multiple mean values (Duncan, 1955). The data were processed in SPSS statistical software (IBM Corp, 2016).

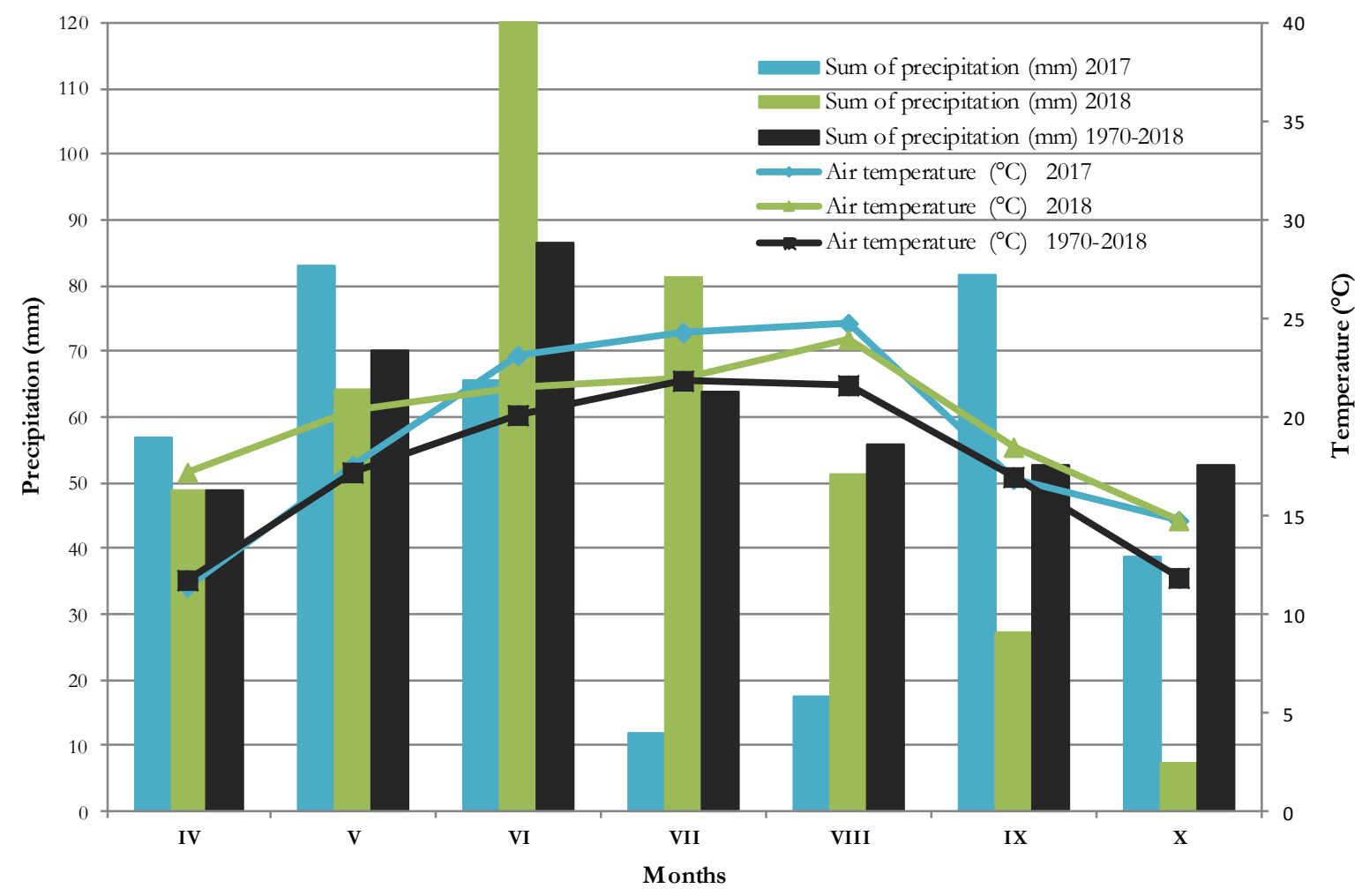

Figure 1. Walter climate diagram 


\section{Results and discussion}

As shown in Figure 1, climatic conditions during the trial were different in 2017 and 2018. Considering that measured traits are influenced by environmental conditions, especially during the flowering and development of the fruit, i.e. BBCH 61-79 phases (Lancashire et al., 1991), it is important to highlight that 2017 was extremely arid with the sum of precipitation very different compared to 2018. The time period of sunflower ripening is also influenced by environmental factors of which temperature and available water content are very important, and its lack leads to a water stress (Dagustu et al., 2010). Intercropping is very favourable in these years because leguminous crops retain moisture and reduce evapotranspiration.

Two-way ANOVA was applied to assess the main effect of each independent variable (hybrid and treatment) and their interaction. Analysis presented in Table 1 shows that the differences in sunflower plant height and head diameter are significantly contributed by the hybrids, treatments and their interactions, so post hoc test was performed.

Statistical analysis also showed significant difference in plant height and head diameter of different sunflower hybrids intercropped with legumes and in control. The analysed combinations showed high variability in sunflower plant height. The average plant height of sunflower ranged from $150.4 \mathrm{~cm}$ (Dukat/CV 2017) to $253.8 \mathrm{~cm}$ (Rimi PR/C 2018). Eleven combinations were found to have a plant height below $200 \mathrm{~cm}$ and thirteen combinations were found to have a plant height over $200 \mathrm{~cm}$. The average head diameter ranged from 14.7 cm (Rimi PR/C 2017) to $22.5 \mathrm{~cm}$ (Dukat/C 2017).

In 2017 hybrid NS Gricko had the lowest plant height when intercropped with common vetch (174.9 $\mathrm{cm})$, and the largest in sole cropping $(221.2 \mathrm{~cm})$. In 2018 the results were the same $(207.9 \mathrm{~cm}$ in common vetch; $239.2 \mathrm{~cm}$ in sole cropping). Statistical analysis of data in 2017 revealed a significant difference between all intercropping combination and control, except between control and red clover. However, in 2018 data analysis showed difference between all intercropping combinations and control, but no differences between red clover and alfalfa combinations. Regarding head diameter, in 2017 it was the smallest in intercropping NS Gricko with common vetch $(15 \mathrm{~cm})$, and the largest when intercropped with red clover and alfalfa $(19.2 \mathrm{~cm} ; 19.9 \mathrm{~cm}$, respectively). In 2018 the largest head diameter was once again in combinations with red clover and alfalfa $(20.6 \mathrm{~cm} ; 20 \mathrm{~cm}$, respectively), but common vetch and control were on the same statistical level. The results indicate that red clover and alfalfa are not significant competitors to sunflower regarding plant height and head diameter (Table 2.).

By its genetic constitution, hybrid Dukat is the lowest of the three hybrids tested in the experiment. In 2017 this hybrid also had the lowest plant height when intercropped with common vetch $150.4 \mathrm{~cm}$, versus $172.6 \mathrm{~cm}$ in control. Statistical analysis also showed significant differences between the combination in which sunflower is intercropped with common vetch and red clover and common vetch and alfalfa, but not between red clover and alfalfa. There was no significant difference between alfalfa and control (Table 3). In 2018 intercropping Dukat with all tree legumes was on the same statistical level, but intercropping Dukat with red clover and in control was also on the same statistical level. Regarding head diameter in 2017 and 2018 only intercropping of Dukat with common vetch (18.1 cm; $20.4 \mathrm{~cm}$, respectively) was statistically lower than in other treatments.

Like other hybrids, hybrid Rimi PR in 2017 had the lowest plant height when intercropped with common vetch $(177.5 \mathrm{~cm})$, and the largest when intercropped

Table 1. Two-way ANOVA identifying differences in sunflower traits across hybrids, treatment and their interaction

\begin{tabular}{lccccccc}
\hline & & \multicolumn{3}{c}{ Plant height } & \multicolumn{3}{c}{ Head diameter } \\
\cline { 2 - 8 } & year & df & F & p & df & F & P \\
\hline \multirow{2}{*}{ Treatment } & 2017 & 3 & 167.235 & 0.000 & 3 & 31.603 & 0.000 \\
\multirow{3}{*}{ Hybrid } & 2018 & 3 & 68.542 & 0.000 & 3 & 15.126 & 0.000 \\
\cline { 2 - 8 } Tx H & 2017 & 2 & 436.124 & 0.000 & 2 & 180.062 & 0.000 \\
& 2018 & 2 & 2878.525 & 0.000 & 2 & 183.971 & 0.000 \\
\cline { 2 - 8 } & 2017 & 6 & 31.887 & 0.000 & 6 & 14.009 & 0.000 \\
& 2018 & 6 & 13.928 & 0.000 & 6 & 4.529 & 0.000 \\
\hline
\end{tabular}

Table 2. Plant height and head diameter of the hybrid NS Gricko intercropped with legumes

\begin{tabular}{lccccc}
\hline trait & year & CV & RC & ALF & C \\
\hline \multirow{2}{*}{ Plant height } & 2017 & $174.9 \pm 15.2^{\mathrm{A}}$ & $215.2 \pm 8.7^{\mathrm{C}}$ & $181.5 \pm 17.5^{\mathrm{B}}$ & $221.2 \pm 11.8^{\mathrm{C}}$ \\
& 2018 & $207.9 \pm 9.4^{\mathrm{A}}$ & $220.5 \pm 10.1^{\mathrm{B}}$ & $221.8 \pm 11.9^{\mathrm{B}}$ & $239.2 \pm 10.8^{\mathrm{C}}$ \\
\cline { 2 - 6 } Head diameter & 2017 & $15 \pm 3^{\mathrm{A}}$ & $19.2 \pm 3^{\mathrm{B}}$ & $19.9 \pm 3.1^{\mathrm{B}}$ & $17.6 \pm 3.1^{\mathrm{C}}$ \\
& 2018 & $18.6 \pm 2.7^{\mathrm{A}}$ & $20.6 \pm 1.8^{\mathrm{B}}$ & $20 \pm 2.3^{\mathrm{B}}$ & $17.9^{\mathrm{B}} 1.8^{\mathrm{A}}$ \\
\hline
\end{tabular}

CV-common vetch; RC-red clover; ALF-alfalfa; C-control; significance at $p<0.05$; values marked with the same letter do not distinguish 
Table 3. Plant height and head diameter of the hybrid Dukat intercropped with legumes

\begin{tabular}{|c|c|c|c|c|c|}
\hline trait & year & $\mathrm{CV}$ & $\mathrm{RC}$ & ALF & $\mathrm{C}$ \\
\hline \multirow{2}{*}{ Plant height } & 2017 & $150.4 \pm 10.3^{\mathrm{A}}$ & $168.1 \pm 6.8^{B}$ & $170.4 \pm 6.4^{\mathrm{BC}}$ & $172.6 \pm 11.2^{\mathrm{C}}$ \\
\hline & 2018 & $158.2 \pm 9.3^{\mathrm{A}}$ & $159.8 \pm 8.9 \mathrm{AB}$ & $158.9 \pm 7.5^{\mathrm{A}}$ & 162. $8 \pm 7.8^{\mathrm{B}}$ \\
\hline \multirow{2}{*}{ Head diameter } & 2017 & $18.1 \pm 2.4^{\mathrm{A}}$ & $22.2 \pm 2.1^{\mathrm{B}}$ & $22.2 \pm 2.7^{\mathrm{B}}$ & $22.5 \pm 3.2^{\mathrm{B}}$ \\
\hline & 2018 & $20.4 \pm 2.6^{\mathrm{A}}$ & $21.9 \pm 2.2^{\mathrm{B}}$ & $21.8 \pm 1.9^{\mathrm{B}}$ & $21.4 \pm 2.3^{\mathrm{AB}}$ \\
\hline
\end{tabular}

CV-common vetch; RC-red clover; ALF-alfalfa; C-control; significance at $\mathrm{p}<0.05$; values marked with the same letter do not distinguish

with alfalfa $(224.4 \mathrm{~cm})$. Results in Table 4 show that plant height was the largest in 2018 in control (253.8 $\mathrm{cm})$ and the lowest when intercropped with common vetch (235.2), but statistically the same with alfalfa combination (235.9). Head diameter of the Rimi PR hybrid in both years is statistically the same in all combinations except in control in 2017 which is significantly lower than the others. This fact indicates that the treatments had no effect on this trait in hybrid Rimi PR.

Sunflower plant height varies to a great extent, depending on genotype, available nutrients, soil moisture content, vegetation space, and other production conditions (Mijić et al. 2005; Iqbal et al. 2013). Reducing plant height is significantly influenced by intercropping of all hybrids with common vetch, since the combination with this legume led to the highest reduction in sunflower plant height, while other treatments varied by year and hybrid. Also, it has been observed that the intensive growth of common vetch suppressed the sunflower growth in the phase of 3-4 pairs of leaves (Figure 2). Results indicate that the combination of sunflower with common vetch reduces plant height in all three hybrids, i.e. it had the greatest negative influence comparing with other treatments or control. In 2017 NS Gricko/RC, Rimi/RC, and Dukat/ ALF combinations were statistically the same as control; as for 2018 this was the fact for Dukat/RC combination. It is considered that intercropping of Rimi PR and NS Gricko with red clover has the least effect on sunflower plant height. Hybrid Dukat intercropped with alfalfa and the same hybrid in sole crop system have similar values, indicating that this combination is best suited for the hybrid Dukat. The study by Saleem et al. (2003), which was aimed at intercropping of sunflower with mungbean and mashbean, indicated that intercropping did not have a significant effect on plant height, which is consistent with the conclusion of this study related to the intercropping of sunflower with alfalfa and red clover. In areas with strong winds and precipitation, high hybrids are susceptible to stem lodging, which leads to difficulties in harvesting, and, as a final result, yields decrease. Marinković (2011) point out that by reducing the height of the plant, the number of plants per hectare may slightly increase and thus the yield per unit area. Due to possibility of lodging, lower stem height increases the stability of sunflower production, so breeders choose lower genotypes during breeding process (Škorić, 2012). Saleem et al. (2003), elucidate that the growth dynamics are most controlled by the genetic constitution of the plant relative to the external growing conditions. It can be concluded that the influence of sunflower intercropping with different plant species depends not only on the genetic constitution of the cultivated hybrid and climate factor, but also on the other plant species in the intercropping system, and their competitiveness with the sunflower.

Head diameter is influenced by genotype and environmental conditions that occur during flowering and fertilisation. Environmental conditions, such as number of plants per unit area, and available amounts of water and nutrients, are important (Mrđa, 2015). The results for the head diameter are more specific regarding the hybrid, which was to be expected. Hybrid NS Gricko had the smallest head diameter when intercropped with common vetch in 2017 and in control in 2018, while in both years this trait was shown to be the largest when intercropping with red clover and alfalfa. Hybrid Dukat had the smallest head diameter statistically significant, in both years, when intercropped with common vetch, which suggests that other treatments did not adversely affect this trait. In 2017 hybrid Rimi PR had the smallest head diameter in control, and in 2018 this trait was the similar results for all treatments. Given that the experiment was performed in years that varied significantly in agroecological conditions, the results indicate that red clover and alfalfa can mitigate the negative effects caused by

Table 4. Plant height and head diameter of the hybrid Rimi PR intercropped with legumes

\begin{tabular}{cccccc}
\hline trait & year & CV & RC & ALF \\
\hline \multirow{2}{*}{ Plant height } & 2017 & $181.5 \pm 15.1^{\mathrm{A}}$ & $218.2 \pm 9.1^{\mathrm{B}}$ & $224.4 \pm 9.6^{\mathrm{C}}$ & $218.1 \pm 13.2^{\mathrm{B}}$ \\
& 2018 & $235.2 \pm 9.4^{\mathrm{A}}$ & $245.3 \pm 10.3^{\mathrm{B}}$ & $235.9 \pm 9.3^{\mathrm{A}}$ & $253.8^{ \pm} 14.8^{\mathrm{C}}$ \\
\cline { 2 - 5 } Head diameter & 2017 & $16.4 \pm 2.3^{\mathrm{A}}$ & $16.5 \pm 1.2^{\mathrm{A}}$ & $15.8^{\mathrm{A}} \pm 2.0^{\mathrm{A}}$ & $14.7 \pm 1.6^{\mathrm{B}}$ \\
& 2018 & $17.4 \pm 2.3^{\mathrm{A}}$ & $17.5 \pm 1.2^{\mathrm{A}}$ & $16.8 \pm 2^{\mathrm{A}}$ & $16.8 \pm 1.6^{\mathrm{A}}$ \\
\hline
\end{tabular}

CV-common vetch; RC-red clover; ALF-alfalfa; C-control; significance at $\mathrm{p}<0.05$; values marked with the same letter do not distinguish 

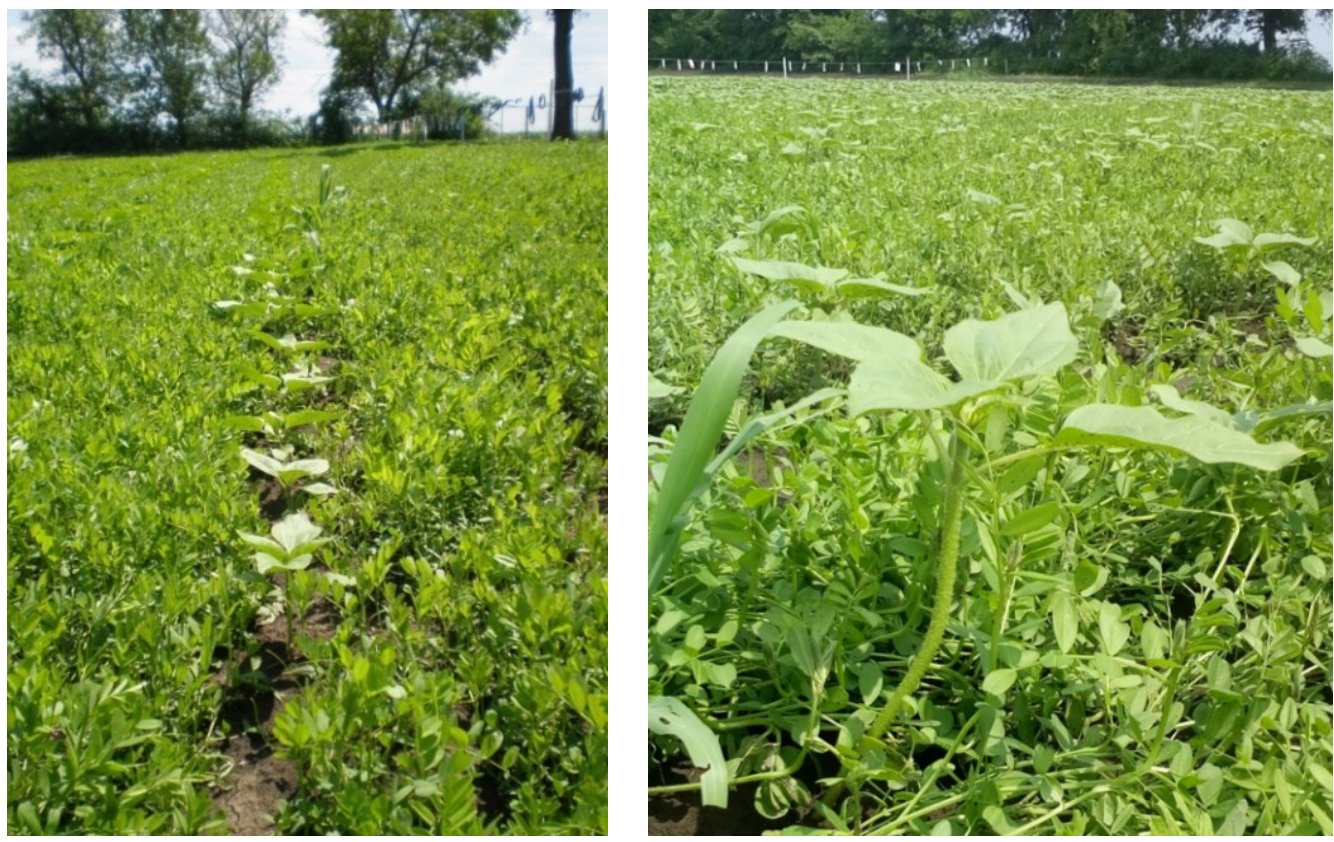

Figure 2. Species competition in the initial stages of growth and development

lack of precipitation and high temperatures. In his confectionary sunflower study, Kholghi et al. (2011) found that yield was positively associated with head diameter, which is to say that it is important to choose combinations whose head diameter is the highest.

\section{Conclusion}

Given that plant height and head diameter of sunflower alter considerably depending on many factors, and compared to the results obtained, it can be concluded that intercropping red clover and alfalfa with sunflower does not exert negative effects on the height of the sunflower plant and its head diameter, so these two species are suitable for further investigation of the influence of intercropping in the direction of sunflower yield, as the most important trait. The results indicate that the combination of sunflower with common vetch can have a negative impact that could be reflected in sunflower seed yield, since investigated traits have a significant direct (in some studies indirect) effect on seed yield. Considering the aforementioned benefits of intercropping with legumes, and in relation to the results of plant height and head diameter, the following combinations of sunflower and legumes are the most desirable: NS Gricko/RC, Dukat/ALF, Dukat/RC and Rimi PR/RC, depending on the agro-ecological conditions. The obtained results can be of practical importance because selecting the right combination for intercropping can improve sunflower production, but also contribute to the conservation of soil and environmental properties, which is of the most importance in the midst of climate change. In order to better understand all aspects of sunflower-legume intercropping, further research is needed, which will include other morphological, qualitative and quantitative indicators. Based on the results presented so far, we can conclude that choosing the right combination can be a step toward more sustainable sunflower production.

\section{References}

Bokan, N., Dugalić, G., Tomić, D., Vasiljević, S., Karagić, Đ., Milić, D., Katanski, S. (2016). The importance of legumes for organic farming. XXI Savetovanje o biotebnologiji, Zbornike radova, 21(23), 23-28.

Crnobarac, J., Malinović, N., Dušanić, N., Meši, M., Mehandžić, R. (2005). Tehnologija gajenja i tehnika u intenzivnoj proizvodnji suncokreta (Cultivation technology and technique in intensive sunflower production). Zbornik radova Instituta za ratarstvo $i$ pourtarstvo, 41, 459-471.

Čurović, O. (2018). Proizvodnja i prerada industrijskog bilja (Production and processing of industrial plants). Poslovna zajednica za industrijsko bilje, Novi Sad.

Dagustu, N., Sincik, M., Bayram, G., Bayraktaroglu, M. (2010). Regeneration of fertile plants from sunflower (Helianthus annuus L.) - Immature embryo. Helia, 33(52), 95-102.

de la Fuente, E., Suárez, S., Lenardis, A., Poggio, S. (2014). Intercropping sunflower and soybean in intensive farming systems: Evaluating yield advantage and effect on weed and insect assemblages, NJAS - Wageningen Journal of Life Sciences, 7071, 47-52.

Duncan, D., B. (1955). Multiple range and multiple F tests. Biometrics 11(1), 1-42.

Haugaard-Nielsen, H., Ambus, P., Jensen, E., S. (2001). Interspecific competition, $\mathrm{N}$ use and interference with weeds in pea barley intercropping. Field Crops Research, 70(2), 101-109.

Hladni, N., Miladinović, D. (2019). Confectionery sunflower breeding and supply chain in Eastern Europe. OCL, 26, 29. DOI:10.1051/ocl/2019019

Hladni, N., Miklič, V., Jocić, S., Kraljević-Balalić, M., Škorić, D. (2014). Mode of inheritance and combining ability for plant height and head diameter in sunflower (Helianthus annuus L.). Genetika, 46(1), 159-168.

Hladni, N., (2007). Combining abilities and mode of inheritance of yield and yield components in sunflower (Helianthus annuus $\mathrm{L}$.). $\mathrm{PhD}$ Thesis, University of Novi Sad, Faculty of Agriculture, Serbia. 
IBM Corp. Released (2016). IBM SPSS Statistics for Windows, Version 24.0. Armonk, NY: IBM Corp.

Iqbal, M., Ijaz, U., Ullah, S., Iqbal, M., Mahmood, K., Najeebullah, M. Abdullah, Niaz S., Sadaqat, H. (2013). Genetic divergence and path coefficient analysis for yield related attributes in sunflower (Helianthus annuus L.) under less water conditions at productive phase. Plant Knowledge Journal 2(1), 20-23.

Kaya, Y., Jocic, S., Miladinovic, D. (2011). Chapter 4: Sunflower. In Gupta, S. K. (Ed.). Technological Innovations in Major World Oil Crops, Volume 1: Breeding (Vol. 1). Springer Science \& Business Media: 85-129.

Kaya, Y. (2016). Sunflower. In: S. K. Gupta, (Ed.). Breeding Oilseed Crops for Sustainable Production, Academic Press, 55-88.

Kholghi, M., Bernousi, I., Darvishzadeh, R., Pirzad, A. (2011) Correlation and Path-Coefficient Analysis of Seed Yield and Yield Related Trait in Iranian Confectionery Sunflower Populations. African Journal of Biotechnology, 10(61), 13058-13063.

Lancashire, P., D., Bleiholder, H., van den Boom, T., Langelüddeke, P., Stauss, R., Weber, E., Witzenberger, A. (1991). A uniform decimal code for growth stages of crops and weeds, Annals of Applied Biology, 119(3), 561-601.

Lalić, B., Mihailović, D. T., Podraščanin, Z. (2011). Future State of Climate in Vojvodina and Expected Effects on Crop Production. Ratarstvo i Povrtarstvo, 48(2), 403-418.

Marinković, R., Jocković, M., Jocić, S., Ćirić, M. (2011). Variability of Plant Height and Head Diameter in New Hybrid Combinations of Sunflower. Ratarstvo i Povrtarstvo 48(1), 239-244.

Martin-Guay, M., O., Paquetteb, A., Duprasa, J., Rivesta, D. (2018). The new Green Revolution: Sustainable intensification of agriculture by intercropping. Science of the Total Environment, 615 (15), 767-772.

Mijić, A., Krizmanić, M., Liović, I., Bilandžić, M., Zdunić, Z., Kozumplik, V. (2005). Estimation of combining abilities and gene effects for plant height and head diameter in sunflower. Poljoprivreda, 11(2), 18-23.

Miklič, V., Dušanić, N., Jocić, S. (2011). Semenska proizvodnja suncokreta (Sunflower seed production). In: Milošević, M., Kobiljski, B. (Ed) Semenarstvo. Institut za ratarstvo i povrtarstvo, Novi Sad, 196-264.
Mrda, J. (2015). The effect of seed quality on the developmental dynamics, yield and quality of sunflower. $\mathrm{PhD}$ Thesis, University of Novi Sad, Faculty of Agriculture, Serbia.

Ren, W., Hu, L., Zhang, J., Sun, C., Tang, J., Yuan, Y., Chen, X. (2014). Can positive interactions between cultivated species help to sustain modern agriculture? Frontiers of Ecology and Environment 12(9), 507-514.

Saleem, R., Farooq, M. U., Ahmed, R. (2003). Bio-economic assessment of different sunflower based intercropping systems at different geometric configurations. Journal of Biological Sciences, 6(13), 1187-1190.

Seiler, G., Qu, L., Marek, L. (2017). Utilization of Sunflower Crop Wild Relatives for Cultivated Sunflower Improvement. Crop Science, 57(3), 1-18.

Singh, B., Gaydon, D., S., Humphreys, E., Yadav, S. (2015). Options for increasing the productivity of the rice-wheat system of north-west India while reducing groundwater depletion. Part 1. Rice variety duration, sowing date and inclusion of mungbean. Field Crops Research, 173, 68-80

Šeremešić, S., Manojlović, M., Ilin, Ž.,Vasić, M., Varga-Gvozdanović, J., Subašić, A., Vojnov, B. (2018). Effect of intercropping on the morphological and nutritional properties of carrots and onions in organic agriculture. Journal on Processing and Energy in Agriculture, 22(2), 80-84.

Šimić, B., Ćosić, J., Liović, I., Krizmanić, M., Poštić, J. (2008). The influence of weather conditions on economic characteristics on sunflower hybrids in macro experiments from 1997 to 2007. Proc. 17th International Sunflower Conference, Cordoba, Spain, 261-263.

Škorić, D. (2012). Sunflower breeding. In: Škorić, D., Sakač, Z. (Ed). Sunflower Genetics and Breeding. Serbian Academy of Sciences (SASA), Branch in Novi Sad, Novi Sad, Republic of Serbia, 165354.

Ugrenović, V., Ugrinović, M. (2014). Pokrovni usevi - ostvarenje održivosti u sistemima ekološke poljoprivrede (Cover crops achieving sustainability in organic farming systems). Organska proizvodnja $i$ biodiveryitet, Zbornike referata / IV otvoreni dani biodiverziteta, Pančevo, 1-15

\section{Uticaj združene setve suncokreta sa leguminozama na neke morfološke osobine suncokreta}

\section{Brankica Babec · Srđan Šeremešić · Nada Hladni · Sreten Terzić · Bojan Vojnov · Nemanja Ćuk · Sonja Grozdenac}

Sažetak: Obzirom da su klimatske promene goruće pitanje današnjice, poljoprivreda se mora okrenuti održivijim i ekološki prihvatljivijim sistemima, kao što je združenja setva. U okviru dvogodišnjeg istraživanja združivanja suncokreta sa leguminozama, ispitan je uticaj ovog sistema na visinu biljaka i prečnik glave suncokreta. Cilj istraživanja bila je procena uticaja združivanja leguminoza sa suncokretom na ove osobine, uzimajući u obzir mogućnost kompeticije između useva. Poljski ogled je postavljen u aprilu 2017. i 2018. godine na eksperimentalnom polju Instituta za ratarstvo i povrtarstvo, Novi Sad, Srbija u umereno-kontinentalnoj klimi. Godina 2017. bila je izuzetno sušna sa količinom padavina različitim u odnosu na 2018. godinu. Visina biljaka i prečnik glave hibrida Rimi PR, Dukat i NS Gricko združenih sa grahoricom, crvenom detelinom i lucerkom uprođeni su sa kontrolom, tj. istim hibridima koji su uzgajani u čistom usevu. Primećeno je da intenzivan početni porast grahorice suzbija rast suncokreta i dovodi do smanjenja visine biljaka i prečnika glave kod sva tri hibrida. Rezultati istraživanja ukazuju na to da su sledeće kombinacije suncokreta i leguminoza najpoželjnije: NS Gricko/RC, Dukat/ALF, Dukat/RC and Rimi PR/RC u zavisnosti od agroekoloških uslova. Obzirom na to da je eksperiment izveden u godinama koje su se značajno razlikovale u agroekološkim uslovima, rezultati pokazuju da crvena detelina i lucerka mogu ublažiti negativne efekte izazvane nedostatkom padavina i visokim temperaturama. Kako bi se bolje razumeli svi aspekti združivanja suncokreta sa leguminozama potrebna su dalja istraživanja koja će uključiti i ostale morfološke, kvalitativne i kvantitativne pokazatelje.

Ključne reči: suncokret, leguminoze, združeni usevi, visina biljke, prečnik glave 